\title{
No evidence for the association of DRD4 with ADHD in a Taiwanese
} population within-family study

\author{
Keeley-Joanne Brookes ${ }^{1}$, Xiaohui Xu1 ${ }^{1}$, Chih-Ken Chen ${ }^{2}$, Yu-Shu Huang' ${ }^{2}$, Yu- \\ $\mathrm{Yu} \mathrm{Wu}^{2}$ and Philip Asherson*1
}

\author{
Address: ${ }^{1}$ MRC Social Genetic Developmental Psychiatry Centre, Institute of Psychiatry, London UK and ${ }^{2}$ Department of Psychiatry, Chang Gung \\ Memorial Hospital, Taiwan \\ Email: Keeley-Joanne Brookes - k.brookes@iop.kcl.ac.uk; Xiaohui Xu - x.xu@iop.kcl.ac.uk; Chih-Ken Chen - ck1094@yahoo.com; Yu- \\ Shu Huang -ck1094@yahoo.com; Yu-Yu Wu - ck1094@yahoo.com; Philip Asherson* - p.asherson@iop.kcl.ac.uk \\ * Corresponding author
}

Published: 05 September 2005

BMC Medical Genetics 2005, 6:31 doi:|0.1 |86/I47|-2350-6-31
Received: 14 January 2005

Accepted: 05 September 2005

This article is available from: http://www.biomedcentral.com/I47/-2350/6/3I

(C) 2005 Brookes et al; licensee BioMed Central Ltd.

This is an Open Access article distributed under the terms of the Creative Commons Attribution License (http://creativecommons.org/licenses/by/2.0), which permits unrestricted use, distribution, and reproduction in any medium, provided the original work is properly cited.

\begin{abstract}
Background: Attention Deficit Hyperactivity Disorder (ADHD) is a prevalent and highly heritable childhood disorder. The dopamine D4 receptor (DRD4) gene has shown a genetic association with ADHD in Caucasian populations with meta-analysis indicating a small but significant effect across datasets. It remains uncertain whether this association can be generalised to non-Caucasian ethnic groups. Here we investigate two markers within the DRD4 gene in a Taiwanese population, the exon 3 variable number tandem repeat (VNTR) and a 5' 120 base-pair duplication.
\end{abstract}

Methods: Within-family transmission disequilibrium tests of association of the $5^{\prime} 120$ base-pair duplication, and exon 3 VNTR in a Taiwanese population.

Results: No evidence of association of ADHD with either polymorphism in this population was observed.

Conclusion: The DRD4 gene markers investigated were not found to be associated with ADHD in this Taiwanese sample. Further work in Taiwanese and other Asian populations will therefore be required to establish whether the reports of association of DRD4 genetic variants in Caucasian samples can be generalised to Asian populations.

\section{Background}

Attention Deficit Hyperactivity Disorder (ADHD) is one of the most prevalent and heritable childhood behavioural disorders. Progress in identifying some of the genes involved in ADHD susceptibility has been relatively fruitful over the past decade by screening genetic variants that lie within or close to genes that regulate neurotransmitter systems, particularly dopamine pathway genes [1]. One of the more consistent findings is the association with the 7 repeat allele of a 48-base pair variable number tandem repeat (VNTR) in exon 3 of D4 receptor gene (DRD4) although there are a number of negative reports and discrepancies between case control and within family studies [2-22]. Meta-analyses of published and unpublished data indicate a small but significant association across datasets with no evidence of heterogeneity $[23,24]$.

Other genetic variants in the DRD4 5'-regulatory region have also been reported to be associated with ADHD. Of particular interest is a 120-bp duplication that has been 
Table I: Allele Frequencies from HHRR analysis and Transmission ratio (T/NT) for TDT. Global and allele-specific tests of association were non-significant.

\begin{tabular}{|c|c|c|c|}
\hline & Case Frequency(\%) & Control (NT) Frequency(\%) & T/NT transmission \\
\hline \multicolumn{4}{|c|}{5 ' marker } \\
\hline $120 \mathrm{bp}$ & 0.232 & 0.236 & $54 / 55$ \\
\hline $240 \mathrm{bp}$ & 0.768 & 0.764 & $179 / 178$ \\
\hline \multicolumn{4}{|c|}{ Exon 3 VNTR } \\
\hline 2 & 0.234 & 0.244 & $46 / 48$ \\
\hline 3 & 0.005 & 0.000 & I / 0 \\
\hline 4 & 0.751 & 0.736 & $|49 /| 46$ \\
\hline 5 & 0.010 & 0.020 & $2 / 4$ \\
\hline
\end{tabular}

associated with ADHD in two studies $[25,26]$ although negative studies have also been reported [27-29,20]. Recently our group investigated the functional significance of this repeat marker using in vitro reporter gene assays and found that the long allele conferred lower transcriptional activity than the shorter alleles in four different mammalian cell lines [30].

Both the 120 bp duplication [10,31] and the exon 3 VNTR [32-35] have also been associated with novelty seeking in a few studies. Although the association with novelty seeking is not as consistent as the association with ADHD and was not significant in a meta-analysis of available data [36], these reports remain of potential interest due the clinical association of ADHD with risk taking and stimulus seeking behaviours [37].

Here we set out to replicate these findings using a Taiwanese sample of 216 ADHD probands that had previously shown association to the dopamine transporter gene [38] (Brookes et al., in review). Grady and colleagues [19] suggest from their detailed analysis of sequence data across DRD4 that in Caucasian populations the 7-repeat allele is a relatively recent mutation that represents an independent clad and has been subject to positive selection. Their data suggests that in Asian populations the 2-repeat allele is a derivative of the Caucasian 7-repeat allele and we might therefore expect to see association between the 2repeat allele and ADHD in Taiwanese populations $[35,44]$. This hypothesis was not supported by Qian et al, $[17,18]$ who did observed a case-control association with long repeat alleles (4-6-repeat alleles; $\mathrm{p}<0.05)$ in a Han Chinese population. This association, however, was not supported using within family tests of association and the association was not specific to any single allele. More recent data from Leung and colleagues does however support this hypothesis by observing a significant increase in prevalence of the 2-repeat allele in a Han Chinese ADHD sample in comparison to a control sample $(\mathrm{p}=0.015)$ [45].

\section{Methods}

216 ADHD probands between the ages of 5-15 years and available parents were recruited into the study from the Child Psychiatric Clinics in the Chang Gung Memorial Hospital in Taipei area, Taiwan. A total of $192(83.6 \%)$ were males. IQ was 50-69 in 13\%, 70-89 in 44\%, 90-119 in $40 \%$ and $>120$ in $1 \%$. The diagnosis of ADHD was made according to DSM-IV criteria following completion of a standard maternal interview (Kiddie-SADS) [39] and completion of parent and teacher Conner's revised rating scales [40]. In all $78 \%$ had the combined subtype and $22 \%$ the inattentive subtype of ADHD.

Genotyping was carried out using standard PCR methods and analysed on $2 \%$ agarose. Detection rate of DRD4 genotypes was $87.5 \%$ for the VNTR and $96 \%$ for the $5^{\prime} 120 \mathrm{bp}$ duplication. Both markers were in Hardy-Weinberg Equilibrium, and no Mendelian errors were observed. The family genotypes were analysed by single marker transmission disequilibrium test (TDT), and haplotype-based haplotype relative risk test (HHRR) run in UNPHASED http://portal.litbio.org/Registered/Menu. UNPHASED was also used to calculate haplotype associations for phase-certain haplotypes (TDTPHASE) and for uncertain haplotypes (HHRR) in addition linkage disequilibrium between the markers.

\section{Results}

The TDT data revealed that neither marker investigated is associated with ADHD in this sample, either individually, or when combined together into a haplotype (Tables 1 and 2). The Global D' value between the two markers is low (0.2) suggesting that the two markers segregate inde- 
Table 2: Haplotype analysis of the two markers did not find either global or haplotype-specific evidence for association.

\begin{tabular}{llllll}
\hline Haplotype & Case $(T)$ & Frequency & Control (NT) & Frequency & OR \\
\hline $1-2$ & 17 & 0.095 & 12 & 0.068 & 1 \\
$1-4$ & 21 & 0.119 & 26 & 0.15 & 0.57 \\
$2-2$ & 25 & 0.144 & 31 & 0.176 & 0.59 \\
$2-3$ & 1 & 0.006 & 0 & 0 & 0.72 \\
$2-4$ & 110 & 0.625 & 103 & 0.583 & 0.77 \\
$2-5$ & 2 & 0.011 & 4 & 0.36 & 0.36 \\
\hline
\end{tabular}

pendently from each other in this population. Refining the sample by removing those with IQ less than 70, did not improve the significance of the finding for either the exon III VNTR (TDT $\mathrm{p}=0.55$; HHRR $\mathrm{p}=0.55$ ), the $5^{\prime} 120$ bp repeat $($ TDT $\mathrm{p}=0.71 ;$ HHRR $\mathrm{p}=0.73)$ or the haplotype of the two markers (TDT $\mathrm{p}=0.45$; HHRR $\mathrm{p}=0.45$ ). Subtype specific tests of association for the combined and inattentive subtypes analysed separately were non-significant (data not shown).

\section{Discussion}

In summary we did not find the DRD4 markers to be associated with ADHD in a Taiwanese sample that has previously shown association with the dopamine transporter gene. As reported in previous studies in Asian populations the VNTR 7-repeat allele was absent and we also failed to replicate the previous reported associations in a Chinese population with 4-repeat and 6-repeat alleles $[17,18]$ and in a Taiwanese population with the 2-repeat allele [45]. There have been no previously reported studies of the 120-bp repeat polymorphism and ADHD in Asian populations. Differences in association may also be due to differential diagnosis because of difference in cultures between western and eastern civilisations [48]. However the previously reported association with the dopamine transporter gene suggests that the clinical phenotype in this sample is comparable with samples ascertained in Europe, the United States and South America.

There are several possible explanations for the observed findings. First it is entirely possible that increased risk to ADHD associated with either of the markers studied may be absent in Asian populations. The association with the 7-repeat allele reported in Caucasian populations may be dependent on the presence of the 7-repeat allele itself and therefore absent from any population with low frequency of this allele. Critical sequences that increase risk for ADHD may therefore be absent in this population. The association with the 120-bp duplication has yet to be established and these data lend no further support to this potential finding. Second, our sample lacked power to detect very small main effects with less than $80 \%$ power at alpha $=0.05$ for odds ratios less than 1.5 for associations with either the 2-repeat or 4-repeat alleles. Furthermore, it is feasible that environmental risk factors might interact with genetic risk factors reducing or abolishing main effects from genotype alone (e.g. $[41,42])$. In this case we would have little chance of detecting such associations unless we also had measured environmental risks. Third, previous studies using within family tests of association have failed to find evidence for association of the VNTR polymorphism with ADHD, whereas case-control designs have been more positive (discussed in [1]). The work of Holmes et al [8] using a collaborative dataset suggests that although there was no preferential transmission of the 7repeat allele, there was a significant TDT association in the sub-group that had co-morbid conduct disorder. This is consistent with a report that parent-proband trios samples have a less severe clinical phenotype with lower levels of ADHD and co-morbid symptoms [43]. The association may therefore be present in co-morbid groups or groups which have certain aspects of the ADHD phenotype such as novelty seeking, cognitive impulsiveness [22], or persistence of symptoms [21] that have not been measured in this sample.

Fourth, it has been noted that for within family tests of association, dropped genotypes or genotyping errors for risk alleles with population frequency of less than 0.5 may give rise to false negative findings [49]. Although we were careful to rule out genotyping errors by identifying and regenotyping ambiguous genotype calls, we did have a high level of dropping genotypes. Both proband and parental genotypes were however in Hardy-Weinberg Equilibrium suggesting that no major genotype biases were affecting this sample. We have attempted to deal with some limitations of within family tests of association by looking for case-control differences for the frequencies of the 2-repeat alleles. Using frequency in Han Chinese controls as 20\% from data published by Leung and colleagues [45] and comparing this to the allele frequency of the 2-repeat of our probands $(23.8 \%)$, there is no significant difference. 
One final explanation may be due to hypothesized reciprocity between ADHD associations with the dopamine transporter and DRD4. As hypothesised by Swanson and colleagues [46] the risk allele for ADHD in the dopamine transporter may represent a hyper-efficient variant, whereas the risk alleles for the dopamine $\mathrm{D} 4$ receptor may represent a sub-sensitive variant, both leading to a hypodopaminergic system. Although additive or epistatic interactions between these two genes are likely, it might also be that they act independently of each other, describing two distinct causes of ADHD. It is therefore possible that samples that have been found to be associated with the DAT1 10-repeat risk allele, may not also be associated to the dopamine receptor D4 risk allele, due to over-representation of one allele or the other in particular populations. For example our UK sample that has also been found to be associated with DAT1 risk variants [47] (Brookes et al, in review), was not found to be associated with the VNTR polymorphism in the dopamine receptor D4 [15]. We investigated this possibility by re-analysing the DRD4 findings separately for individuals homozygous for the dopamine transporter risk allele and those with less than two risk alleles however there was no suggestion of association in these two sub-groups (data not shown).

\section{Conclusions}

These results taken together with other reports of Taiwanese and Asian samples find no consistency in the association between genetic variants of DRD4 and ADHD. Further work in Taiwanese and other Asian populations will therefore be required to establish whether the reports of association of DRD4 genetic variants in Caucasian samples can be generalised to Asian populations.

\section{Abbreviations \\ DRD4 - Dopamine Receptor D4, ADHD - Attention Def- icit Hyperactivity Disorder, TDT - Transmission Disequi- librium Test, HHRR - Haplotype-based Haplotype Relative Risk, VNTR - Variable Number Tandem Repeat.}

\section{Competing interests}

The author(s) declare that they have no competing interests.

\section{Authors' contributions}

Keeley Brookes and Philip Asherson selected the markers for analysis. Keeley Brookes carried out the genotyping of the population and performed statistical analysis under the supervision of Philip Asherson. DNA was provided by Chih-Ken Chen, Yu-Shu Huang and Yu-Yu Wu. DNA was organised by Xiaohui Xu. Philip Asherson directed the study.

\section{Acknowledgements}

This research was funded by research grants in the UK from the Medical Research Council and the Wellcome Trust and in Taiwan from the Depart- ment of Psychiatry, Chan Gung Memorial Hospital and the Taipei City Psychiatric Centre. We thank all families for their participation in this research.

\section{References}

I. Asherson P: Attention Deficit Hyperactivity Disorder in PostGenomic Era. European Journal of Child and Adolescent Psychiatry 2004.

2. LaHoste GJ, Swanson JM, Wigal SB, Glabe C, Wigel T, King N, Kennedy JL: Dopamine D4 Receptor Gene Polymorphism Is Association With Attention Deficit Hyperactivity Disorder. Molecular Psychiatry 1996, I(2): I21-124.

3. Swanson JM, Sunohara GA, Kennedy JL, Regino R, Fineberg E, Wigal T, Lerner M, Williams L, LaHoste G], Wigal S: Association of the Dopamine Receptor D4 (DRD4) Gene With a Refined Phenotype of Attention Deficit Hyperactivity Disorder (ADHD): A Family-Based Approach. Molecular Psychiatry 1998, 3(I):38-4I.

4. Smalley SL, Bailey JN, Palmer CG, Cantwell DP, McGough JJ, Del'Homme MA, Asarnow JR, Woodward JA, Ramsey C, Nelson SF: Evidence That the Dopamine D4 Receptor Is a Susceptibility Gene in Attention Deficit Hyperactivity Disorder. Mol Psychiatry 1998, 3(5):427-430.

5. Faraone SV, Biederman J, Weiffenbach B, Keith T, Chu MP, Weaver A, Spencer TJ, Wilens TE, Frazier J, Cleves M, Sakai J: Dopamine D4 Receptor Gene 7-Repeat Allele and Attention Deficit Hyperactivity Disorder. Am J Psychiatry 1999, I56(5):768-770.

6. Sunohara GA, Roberts W, Malone M, Schachar RJ, Tannock R, Basile VS, Wigal T, Wigal SB, Schuck S, Moriarty J, Swanson JM, Kennedy JL, Barr CL: Linkage of the Dopamine D4 Receptor Gene and Attention-Deficit/Hyperactivity Disorder. J Am Acad Child Adolesc Psychiatry 2000, 39( I 2): I537-I542.

7. Holmes J, Payton A, Barrett JM, Hever T, Fitzpatrick H, Trumper AL, Harrington R, McGuffin P, Ollier W, Worthington J, Thapar A: A Family-Based Study and Case-Control Study of the Dopamine D4 Receptor Gene and Dopamine Transporter Gene in Attention Deficit Hyperactivity Disorder. Molecular Psychiatry 2000, 5(5):523-530.

8. Holmes J, Payton A, Barrett J, Harrington R, McGuffin P, Ollier W, Worthington J, Gill M, Kirley A, Hawi Z, Fitzgerald M, Asherson P, Curran S, Mill J, Gould A, Taylor E, Kent L, Craddock N, Thapar A: Association of DRD4 in Children With ADHD and Comorbid Conduct Problems. Am J Med Genet 2002, I I 4(2): I50-I53.

9. Tahir E, Yazgan Y, Cirakoglu B, Ozbay F, Waldman I, Asherson PJ: Association and Linkage of DRD4 and DRD5 With Attention Deficit Hyperactivity Disorder (ADHD) in a Sample of Turkish Children. Mol Psychiatry 2000, 5(4):396-404.

10. Kotler M, Manor I, Sever Y, Eisenberg J, Cohen H, Ebstein RP, Tyano S: Failure to Replicate an Excess of the Long Dopamine D4 Exon III Repeat Polymorphism in ADHD in a Family-Based Study. Am J Med Genet 2000, 96(3):278-28I.

II. Muglia P, Jain U, Macciardi F, Kennedy JL: Adult Attention Deficit Hyperactivity Disorder and the Dopamine D4 Receptor Gene. Am J Med Genet 2000, 96(3):273-277.

12. Eisenberg J, Zohar A, Mei-Tal G, Steinberg A, Tartakovsky E, Gritsenko I, Newmanov L, Ebstein RP: A haplotype relative risk study of the dopamine D4 receptor (DRD4) exon III repeat polymorphism and Attention Deficit Hyperactivity Disorder (ADHD). J Med Genet 2000, 96(3):258-26I.

13. Hawi Z, McCarron M, Kirley A, Daly G, Fitzgerald M, Gill M: No Association of the Dopamine DRD4 Receptor (DRD4) Gene Polymorphism With Attention Deficit Hyperactivity Disor$\operatorname{der}$ (ADHD) in the Irish Population. Am J Med Genet 2000, 96(3):268-272.

14. Payton A, Holmes J, Barrett JH, Hever T, Fitzpatrick $\mathrm{H}$, Trumper AL, Harrington R, McGuffin P, O'Donovan M, Owen M, Ollier W, Worthington J, Thapar A: Examining for Association Between Candidate Gene Polymorphisms in the Dopamine Pathway and Attention-Deficit Hyperactivity Disorder: a Family-Based Study. Am J Med Genet 200I, 105(5):464-470.

15. Mill J, Curran S, Kent L, Richards S, Gould A, Virdee V, Huckett L, Sharp J, Batten C, Fernado S, Simanoff E, Thompson M, Zha J, Sham P, Taylor E, Asherson P: Attention Deficit Hyperactivity Disorder (ADHD) and the Dopamine D4 Receptor Gene: Evidence of Association but No Linkage in a UK Sample. Molecular Psychiatry 200I, 6(4):440-444. 
16. Manor I, Tyano S, Eisenberg J, Bachner-Melman R, Kotler M, Ebstein RP: The Short DRD4 Repeats Confer Risk to Attention Deficit Hyperactivity Disorder in a Family-Based Design and Impair Performance on a Continuous Performance Test (TOVA). Molecular Psychiatry 2002, 7(7):790-794.

17. Qian Q, Wang Y, Li J, Yang L, Wang B, Zhou R: Association Studies of Dopamine D4 Receptor Gene and Dopamine Transporter Gene Polymorphisms in Han Chinese Patients With Attention Deficit Hyperactivity Disorder. Beijing Da Xue Xue Bao 2003, 35(4):4|2-4|8.

18. Qian Q, Wang Y, Zhou R, Yang L, Faraone SV: Family-Based and Case-Control Association Studies of DRD4 and DATI Polymorphisms in Chinese Attention Deficit Hyperactivity Disorder Patients Suggest Long Repeats Contribute to Genetic Risk for the Disorder. Am J Med Genet B Neuropsychiats Genet 2004, I 28B(I):84-89.

19. Grady DL, Chi HC, Ding YC, Smith M, Wang E, Schuck S, Flodmen D, Spence MA, Swanson JM, Moyis RK: High Prevalence of Rare Dopamine Receptor D4 Alleles in Children Diagnosed With Attention Deficit Hyperactivity Disorder. Molecular Psychiatry 2003, 8(5):536-545.

20. Kustanovich V, Ishii J, Crawford L, Yang M, McGough JJ, McCracken JT, Smalley SL, Nelson SF: Transmission Disequilibrium Testing of Dopamine-Related Candidate Gene Polymorphisms in ADHD: Confirmation of Association of ADHD With DRD4 and DRD5. Molecular Psychiatry 2004, 9(7):7II-7I7.

21. El-Faddagh M, Laucht M, Maras A, Vohringer L, Schmidt MH: Association of Dopamine D4 Receptor (DRD4) Gene With Attention Deficit Hyperactivity Disorder (ADHD) in a High Risk Community Sample: A Longitudinal Study From Birth to II Years of Age. J Neural Transm 2004, I I I (7):883-889.

22. Langley K, Marshall L, van den Bree M, Thomas H, Owen M, O'Donovan M, Thapar A: Association of the Dopamine D4 Receptor Gene 7-Repeat Allele With Neuropsychological Test Performance of Children With ADHD. Am J Psychiatry 2004, 161(1):133-138

23. Faraone SV, Doyle AE, Mick E, Biederman J: Meta-Analysis of the Association Between the 7-Repeat Allele of the Dopamine D4 Receptor Gene and Attention Deficit Hyperactivity Disorder. Am J Psychiatry 200I, I 58(7): I052-I057.

24. Maher BS, Marazita ML, Ferrell RE, Vanyukov MM: Dopamine system genes and Attention Deficit Hyperacitivty Disorder: A meta-analysis. Psychiatry Genetics 2002, I 2(4):207-2 15.

25. McCracken JT, Smalley SL, McGough JJ, Crawford L, Del'Homme M, Cantor RM, Liu A, nelson SF: Evidence for linkage of a tandem duplication polymorphism upstream of the dopamine D4 receptor gene (DRD4) with Attention Deficit Hyperactivity Disorder (ADHD). Mol Psychiatry 2000, 5(5):53I-536.

26. Arcos-Burgos M, Castellanos FX, Konecki D, Lopera F, Pineda D, Palacio JD, Rapoport JL, Berg K, Bailey-Wilson J, Muenke M: Pedigree Disequilibrium Test (PTD) replicates association and linkage between DRD4 and ADHD in multigenerational and extended pedigree from genetic isolate. Molecular Psychiatry 2004, 9(3):252-259.

27. Barr CL, Feng $Y$, Wigg KG, Schachor R, Tannock R, Roberts $W$, Malone $M$, Kennedy JL: 5 'untranslated region of the dopamine D4 receptor gene and Attention Deficit Hyperactivity Disorder. Am J Med Genet 200I, I 05(I):84-90.

28. Todd RD, Neuman RJ, Cobos EA, Jong YS, Reich W, Heath AC: Lack of association of dopamine $D 4$ receptor gene polymorphism with ADHD subtype in a population sample of twins. Am J Med Genet 200I, I05(5):432-438.

29. Mill JS, Caspi A, McClay J, Sugden K, Purcell S, Asherson P, Craig I, McGuffin P, Briathwaite A, Poulton R, Moffitt TE: The dopamine D4 receptor and the hyperactivity phenotype: A developmental-epidemiological study. Mol Psychiatry 2004, 7(4):383-39I.

30. D'Souza UM, Russ C, Tahir E, Mill J, McGuffin P, Asherson PJ, Craig IW: Functional Effects of a Tandem Duplication Polymorphism in the 5'Flanking Region of the DRD4 Gene. Biol Psychiatry 2004, 56(9):691-697.

31. Rogers G, Joyce P, Mulder R, Sellmon D, Miller A, Allington M, Olds $r$, Wells E, Kennedy M: Association of a duplicated repeat polymorphism in the 5 'untranslted region of the DRD4 gene with novelty seeking. Am J Med Genet B Neurophsychiatr Genet 2004, | 26:95-98.
32. Strobel A, Lesch KP, Jatzke S, Paetzold F, Brocke B: Further evidence for a modulation of novelty seeking by DRD4 Exon III, 5-HTTLPR and COMT Val/Met variants. Molecular Psychiatry 2003, 8(4):37|-372.

33. Keltikangas-Jartinen L, Elovaninio M, Kivimaki M, Lichtermann E, Ekelund J, Peltonen L: Association between the type 4 dopamine receptor gene polymorphism and novelty seeking. Psychosom Med 2003, 65(3):47I-476.

34. Luciano M, Zhu G, Kirk KM, Whitfield JB, Bolter R, Heath AC, Madden PA, Martin NG: Effects of Dopamine Receptor D4 variants on alcohol and tobacco use and on novelty seeking: multivariate linkage and association analysis. Am J Med Genet 2004, I 24B(I): I 13-123.

35. Wang E, Ding YC, Flodman P, Kidd JR, Kidd KK, Grady DL, Ryder OA, Spence MA, Swanson JM, Moyzis RK: The genetics architecture of selection at the human dopamine receptor D4 (DRD4) gene locus. Am J Hum Genet 2004, 74(5):93I-944.

36. Kluger AN, Siegfried Z, Ebstein RP: A meta-analysis of the association between DRD4 polymorphism and novelty seeking. Mol Psychiatry 2002, 7(7):7|2-7|7.

37. Brimer E, Levine FM: Stimulus seeking behaviour in hyperactive and non hyperactive children. J Abnormal Child Psychology I983, I I(I): I3I-I39.

38. Chen CK, Chen SL, Mill J, Huang YS, Lin SK, Curran S, Purcell S, Sham $P$, Asherson $P$ : The dopamine transporter gene is associated with Attention Deficit Hyperactivity Disorder in a Taiwanese sample. Molecular Psychiatry 2003, 8(4):393-396.

39. Kaufman J, Birmaker B, Brent D, Rau U, Flynn C, Moneci P: Schedule for affective disorders and schizophrenia for school-age children - present and lifetime version (K-SADS-PL): inital reliability and validity data. I Am Acad Child and Adolscent Psychiatry 1997, 36:980.

40. Conners CK: The Conners rating scale: Instruments for the assessments of childhood psychopathology. Duke University 1995

4I. Kahn RS, Khoury J, Nichols WC, Laiphear BP: Role of dopamine transporter genotype and maternal prenatal smoking in childhood hyperactivity - impulsive, inattention and oppositional behaviour. J Pediatr 2003, I43(I): I04-II 0.

42. Maughan B, Taylor A, Caspi A, Moffit TE: Prenatal Smoking and Early Childhood Conduct Problems: Testing Genetic and Environment Explanations of the Association. Archives of General Psychiatry 2004, 6 I (8):836-843.

43. West SL, Hulsow M, Arredondo R: Factor Analysis of the Attention Deficit Scales for Adults (ADSA) With a Clinical Sample of Outpatient Substance Abusers. Am J Addict 2003, I2(2): 159-165.

44. Ding YC, Chi HC, Grady DL, Morishima A, Kidd JR, Kidd KK, Flodman P, Spence MA, Schuck S, Swanson JM, Zhang YP, Moyzis RK: Evidence of Positive Selection Acting at the Human Dopamine Receptor D4 Gene Locus. Proc Natl Acad Sci USA 2002, 99(I):309-314.

45. Leung PW, Lee CC, Hung SF, Ho TP, Tang CP, Kwong SL, Leung SY, Yuen ST, Lieh-Mak F, Oosterlaan J, Grady D, Harxhi A, Ding YC, Chi HC, Flodman P, Schuck S, Spence MA, Moyzis R, Swanson J: Dopamine Receptor D4 (DRD4) Gene in Han Chinese Children With Attention-Deficit/Hyperactivity Disorder (ADHD): Increased Prevalence of the 2-Repeat Allele. Am J Med Genet B Neuropsychiatr Genet 2005, I33(I):54-56.

46. Swanson JM, Flodman P, Kennedy J, Spence MA, Moyzis R, Schuck S, Murias M, Moriarity J, Barr C, Smith M, Posner M: Dopamine Genes and ADHD. Neurosci Biobehav Rev 2000, 24(I):2I-25.

47. Curran S, Mill J, Tahir E, Kent L, Richards S, Gould A, Huckett L, Sharp J, Batten C, Fernando S, Ozbay F, Yazgan Y, Simonoff E, Thompson M, Taylor E, Asherson P: Association Study of a Dopamine Transporter Polymorphism and Attention Deficit Hyperactivity Disorder in UK and Turkish Samples. Mol Psychiatry 200I, 6:425-8

48. Mann EM, Ikeda Y, Mueller CW, Takahashi A, Tao KT, Humris E, Li $\mathrm{BL}$, Chin D: Cross-Cultural Differences in Rating HyperactiveDisruptive Behaviors in Children. Am J Psychiatry 1992, I 49(II): I539-1542.

49. Mitchell AA, Cutler DJ, Chakravarti A: Undetected Genotyping Errors Cause Apparent Overtransmission of Common Alleles in the Transmission/Disequilibrium Test. Am J Hum Genet 2003, 72(3):598-610. 


\section{Pre-publication history}

The pre-publication history for this paper can be accessed here:

http://www.biomedcentral.com/1471-2350/6/31/prepub

Publish with Bio Med Central and every scientist can read your work free of charge

"BioMed Central will be the most significant development for disseminating the results of biomedical research in our lifetime. " Sir Paul Nurse, Cancer Research UK

Your research papers will be:

- available free of charge to the entire biomedical community

- peer reviewed and published immediately upon acceptance

- cited in PubMed and archived on PubMed Central

- yours - you keep the copyright 